\title{
Achieving health gain through clinical guidelines II: Ensuring guidelines change medical practice
}

\author{
University of \\ Aberdeen, \\ Foresterhill, Aberdeen \\ AB9 2ZD \\ Jeremy M Grimshaw, \\ senior lecturer, \\ department of general \\ practice \\ Ian T Russell, director, \\ health services research \\ unit \\ Correspondence to: \\ Dr J M Grimshaw, \\ Department of General \\ Practice, University of \\ Aberdeen, Foresterhill \\ Health Centre, Westburn \\ Road, Aberdeen AB9 2ZD \\ Accepted for publication \\ 24 March 1994
}

\begin{abstract}
"Clinical guidelines are proliferating on both sides of the Atlantic." Nevertheless there is considerable uncertainty whether this will improve clinical practice. $^{2}$ We therefore systematically reviewed published evaluations of clinical guidelines. ${ }^{3}$ We identified 59 rigorous evaluations covering a wide range of clinical activities, all but four of which detected statistically significant improvements in the process of medical care and all but two of the 11 that also measured the outcome of care reported statistically significant improvements in outcome. We concluded that guidelines improve clinical practice and achieve health gains when introduced in the context of rigorous evaluations.
\end{abstract}

Within the United Kingdom, clinical guidelines are likely to be incorporated into contracts between purchasers and providers. ${ }^{4}$ However, if these guidelines are to achieve the health gains reported in our review, ${ }^{3}$ two things are needed. Firstly, purchasers and providers should identify scientifically valid guidelines in the sense that, when followed, they lead to the health gains projected for them. ${ }^{5}$ To this end we have proposed a classification of factors influencing the validity of guidelines, designed to inform choice about which guidelines should be integrated into contracts. Greater validity is likely to follow from the use of systematic literature reviews, of independent guideline development groups including representatives of all key disciplines, and of explicit links between recommendations and scientific evidence. ${ }^{5}$ Secondly, purchasers and providers should ensure that these scientifically valid guidelines are successfully introduced, in the sense that medical practice is significantly changed in the direction proposed by the guidelines, thus leading to health gain. The successful introduction of guidelines is dependent on many factors, including the clinical context and the methods by which they are developed, disseminated, and implemented. ${ }^{6}$ Different methods are appropriate in different contexts. In this paper we tabulate the methods adopted by the studies identified by our review (tables $1-3)^{3}$ and propose a framework for successful introduction of guidelines, covering development, dissemination, and implementation strategies. We use the term "dissemination strategy" to describe educational interventions that aim at influencing targeted clinicians' attitudes to, and awareness, knowledge, and understanding of, a set of guidelines and we use "implementation strategy" to describe interventions that aim at improving targeted clinicians' compliance with guideline recommendations (that is, to turn changes in attitudes and knowledge into changes in medical practice). Although this distinction is helpful in exploring the process of introduction of guidelines, we recognise that some interventions influence both dissemination and implementation.

\section{Development strategies}

In developing clinical guidelines the aim is to produce explicit recommendations that are both scientifically valid and helpful in clinical practice. We previously discussed factors that may influence the development of scientifically valid guidelines. ${ }^{5}$ We now consider factors associated with the successful introduction of guidelines, including who develops them, how they are developed, and how they are presented.

WHO SHOULD DEVELOP GUIDELINES?

Guidelines can be developed by internal groups (composed entirely of the clinicians who will use them), intermediate groups (including some of the clinicians who will use them), or external groups (none of whom will use them). ${ }^{5}$ Studies evaluating internal, intermediate, or external guidelines all observed significant changes in clinical behaviour. Three studies directly compared the success of internal guidelines and local external guidelines (table 1). Sommers et al, evaluating guidelines for managing unexplained anaemia in four community hospitals in the United States, observed that, though the introduction of internal guidelines had no effect on compliance, that of local external guidelines increased compliance. ${ }^{16}$ In contrast, Putnam and Curry reported a greater increase in compliance when Canadian family physicians developed their own guidelines for five common conditions than when they received guidelines developed by others. ${ }^{19}$ Similarly, in the North of England Study of Standards and Performance in General Practice, which compared the success of internal guidelines and local external guidelines for five common paediatric conditions, significant changes in process and in outcome were apparent only when general practitioners developed their own guidelines. ${ }^{28}$

Although fewer resources are needed to disseminate and implement internal guidelines than intermediate or external guidelines, ${ }^{3}$ internal guidelines are less likely to be scientifically valid ${ }^{5}{ }^{68}$ because local groups lack the clinical, managerial, and technical skills 
Table 1 Development, dissemination, and implementation strategies adopted by rigorous evaluations of guidelines for clinical care ${ }^{5}$

\begin{tabular}{|c|c|c|c|c|c|c|c|}
\hline Year & Authors & Subject & $\begin{array}{l}\text { Type of } \\
\text { guideline }\end{array}$ & Method of dissemination & Method of implementation & $\begin{array}{l}\text { Effect on } \\
\text { process }\end{array}$ & $\begin{array}{l}\text { Effect on } \\
\text { outcomic }\end{array}$ \\
\hline 1976 & McDonald & $\begin{array}{l}\text { Diabetes and various } \\
\text { medical conditions }\end{array}$ & External local & None reported & $\begin{array}{l}\text { Computer generated } \\
\text { reminder in notes }\end{array}$ & +++ & \\
\hline 1976 & McDonald ${ }^{*}$ & $\begin{array}{l}\text { Various medical } \\
\text { conditions }\end{array}$ & External local & None reported & $\begin{array}{l}\text { Computer generated } \\
\text { reminder in notes }\end{array}$ & +++ & \\
\hline 1978 & Barnett et al & Streptococcal sore throat & Intermediate & $\begin{array}{l}\text { Guidelines "determined" by } \\
\text { medical and nursing staff }\end{array}$ & $\begin{array}{l}\text { Failure to comply caused } \\
\text { computer generated } \\
\text { reminder following } \\
\text { consultation }\end{array}$ & ++ & \\
\hline 1978 & $\begin{array}{l}\text { Sanazaro and } \\
\text { Worth" }\end{array}$ & $\begin{array}{l}\text { Various medical, } \\
\text { surgical, and paediatric } \\
\text { conditions }\end{array}$ & External national & $\begin{array}{l}\text { Guidelines approved by } \\
\text { medical staff }\end{array}$ & $\begin{array}{l}\text { Guidelines inserted in } \\
\text { patients notes }\end{array}$ & + & () \\
\hline 1980 & Hopkins et al ${ }^{11}$ & Hypotensive shock & External local & $\begin{array}{l}\text { Residents instructed in use } \\
\text { of guidelines for } 30 \text { minutes }\end{array}$ & $\begin{array}{l}\text { Copy of guidelines carried } \\
\text { by residents }\end{array}$ & ++++ & ++ \\
\hline 1980 & Linn'2 & Management of burns & External national & $\begin{array}{l}\text { Seminar lasting } 4 \text { hours } \\
\text { focusing on guidelines }\end{array}$ & $\begin{array}{l}\text { Copy of guidelines kept in } \\
\text { emergency department }\end{array}$ & + & ++ \\
\hline 1980 & McDonald ${ }^{13}$ & $\begin{array}{l}\text { Various medical } \\
\text { conditions }\end{array}$ & External local & $\begin{array}{l}\text { Supporting publications } \\
\text { available on request }\end{array}$ & $\begin{array}{l}\text { Computer generated } \\
\text { reminder ( }+1-\text { bibliographic } \\
\text { citation }) \text { in notes }\end{array}$ & ++ & \\
\hline 1983 & Barnett et al ${ }^{1 t}$ & Hypertension & External local & None reported & $\begin{array}{l}\text { Failure to comply caused } \\
\text { computer generated } \\
\text { reminder following } \\
\text { consultation }\end{array}$ & ++++ & ++ \\
\hline 1983 & Thomas et al ${ }^{15}$ & Diabetes & External local & None reported & $\begin{array}{l}\text { Computer generated } \\
\text { reminder in notes }\end{array}$ & ++ & 0 \\
\hline \multirow[t]{2}{*}{1984} & $\begin{array}{l}\text { Sommers } \\
\text { ct } a l^{10}\end{array}$ & Unexplained anaemia & $\begin{array}{l}\text { Intenal and } \\
\text { external }\end{array}$ & Internal post & $\begin{array}{l}\text { Phase } 1 \text { feedback on } \\
\text { baseline compliance }\end{array}$ & ++ & \\
\hline & & & & & $\begin{array}{l}\text { Phase } 2 \text { - failure to comply } \\
\text { caused computer generated } \\
\text { reminder after consultation }\end{array}$ & ++++ & - \\
\hline 1985 & $\begin{array}{l}\text { Norton and } \\
\text { Dempsey }\end{array}$ & Cystitis and raginitis & Internal & None reported & $\begin{array}{l}\text { Feedback on baseline } \\
\text { compliance }\end{array}$ & +++ & \\
\hline 1985 & Palmer et al ${ }^{1 n}$ & $\begin{array}{l}\text { Various medical and } \\
\text { paediatric conditions }\end{array}$ & Intermediate & $\begin{array}{l}\text { Guidelines discussed, } \\
\text { assessed, and then posted }\end{array}$ & $\begin{array}{l}\text { Feedback on baseline } \\
\text { compliance discussed then } \\
\text { posted }\end{array}$ & ++ & \\
\hline 1985 & $\begin{array}{l}\text { Putnam and } \\
\text { Curry }^{19}\end{array}$ & $\begin{array}{l}\text { Various medical } \\
\text { conditions }\end{array}$ & $\begin{array}{l}\text { Two internal, } \\
\text { three external }\end{array}$ & External guidelines posted & $\begin{array}{l}\text { Interview with feedback on } \\
\text { baseline compliance, } \\
\text { subsequent personal } \\
\text { educational package }\end{array}$ & ++++ & \\
\hline 1986 & $\begin{array}{l}\text { Brownbridge } \\
\text { et } \mathrm{al}^{20}\end{array}$ & Hypertension & Intermediate & $\begin{array}{l}\text { Guidelines discussed with } \\
\text { participants }\end{array}$ & $\begin{array}{l}\text { Paper or computerised } \\
\text { protocol as part of medical } \\
\text { record }\end{array}$ & ++ & \\
\hline 1986 & $\begin{array}{l}\text { McAlister } \\
\text { et } \mathrm{al}^{21}\end{array}$ & Hypertension & $\begin{array}{l}\text { External } \\
\text { provincial }\end{array}$ & $\begin{array}{l}\text { Guidelines posted to all } \\
\text { participants }\end{array}$ & $\begin{array}{l}\text { Computer generated } \\
\text { reminder in notes }\end{array}$ & 0 & ++ \\
\hline 1986 & $\begin{array}{l}\text { Wirtschafter } \\
\text { et } a l^{22}\end{array}$ & $\begin{array}{l}\text { Neonatal respiratory } \\
\text { distress syndrome }\end{array}$ & External local & $\begin{array}{l}\text { Lectures lasting } 3 \text { hours } \\
\text { with/without training in } \\
\text { protocol use }\end{array}$ & $\begin{array}{l}\text { Protocol embedded within } \\
\text { medical record }\end{array}$ & + & \\
\hline 1987 & Kosecoff et al & $\begin{array}{l}\text { Breast cancer, caesarean } \\
\text { section, coronary artery } \\
\text { bypass grafting }\end{array}$ & External national & $\begin{array}{l}\text { Published in medical press } \\
\text { posted to relevant } \\
\text { professionals }\end{array}$ & None & 0 & \\
\hline 1989 & Lomas et $a l^{24}$ & Caesarean section & External national & $\begin{array}{l}\text { Published in medical press, } \\
\text { posted to relevant } \\
\text { professionals }\end{array}$ & None & + & \\
\hline \multirow[t]{2}{*}{1991} & Lomas et al ${ }^{25}$ & Caesarean section & External national & $\begin{array}{l}\text { (A) Educational programme } \\
\text { led by opinion leader }\end{array}$ & (A) None & ++ & \\
\hline & & & & $\begin{array}{l}\text { (B) Local guideline } \\
\text { adaptation }\end{array}$ & $\begin{array}{l}\text { (B) Aggregated feedback } \\
\text { and discussion of hospital } \\
\text { compliance }\end{array}$ & () & \\
\hline 1992 & $\begin{array}{l}\text { Durand- } \\
\text { Zaleski et } \text { al }^{20}\end{array}$ & Hypovolaemia & External national & $\begin{array}{l}\text { Internal post to all doctors, } \\
\text { meetings for all prescribers }\end{array}$ & $\begin{array}{l}\text { Monthly feedback on total } \\
\text { albumin use and cost to all } \\
\text { prescribers }\end{array}$ & ++++ & \\
\hline 1992 & Margolis et $\mathrm{al}^{2 i}$ & Six paediatric conditions & External local & $\begin{array}{l}\text { Clinicians adapted } \\
\text { guidelines for local use }\end{array}$ & $\begin{array}{l}\text { Protocol within } \\
\text { computerised medical record }\end{array}$ & +++ & \\
\hline 1992 & $\begin{array}{l}\text { North of } \\
\text { England Study } \\
\text { of Standards } \\
\text { and } \\
\text { Performance in } \\
\text { General } \\
\text { Practice }\end{array}$ & $\begin{array}{l}\text { Five paediatric } \\
\text { conditions }\end{array}$ & $\begin{array}{l}\text { Internal and } \\
\text { external }\end{array}$ & External guidelines posted & $\begin{array}{l}\text { Feedback on baseline } \\
\text { compliance }\end{array}$ & + & ++++ \\
\hline 1992 & Sherman et $a l^{20}$ & $\begin{array}{l}\text { Localised prostatic } \\
\text { carcinoma }\end{array}$ & External national & $\begin{array}{l}\text { Published in medical press, } \\
\text { posted to relevant } \\
\text { professionals }\end{array}$ & None & 0 & - \\
\hline 1993 & Emslie et al ${ }^{3,}$ & Infertility & Intermediate & $\begin{array}{l}\text { Posted to relevant } \\
\text { professionals }\end{array}$ & $\begin{array}{l}\text { Protocol embedded within } \\
\text { medical record }\end{array}$ & +++ & \\
\hline
\end{tabular}

Outcome not measured.

0) No significant improvement.

$+\quad$ Significant improvement $<10 \%$ in absolute terms.

++ Significant improvement $10-19.9 \%$ in absolute terms.

+++ Significant improvement $20-29.9 \%$ in absolute term

++++ Significant improvement $\geqslant 30 \%$ in absolute terms

needed to develop guidelines. ${ }^{69} 7072$ Furthermore, greater resources in total are needed to develop internal guidelines. ${ }^{68}$ In Scotland the Clinical Resource and Audit Group has recently proposed an attractive solution to the potentially conflicting demands of developing a guideline that is both scientifically valid and likely to change medical practice..$^{53}$ It suggests that resources should be devoted to the development of national scientifically valid guidelines which can be modified locally to reflect context and resources. Nevertheless, further research is required to identify the most effective forum for developing guidelines, whether national or local.

HOW SHOUI.1) GUIDELINES BE DEVEI.OPED? The methods used to develop guidelines include consensus conferences, peer groups, and the Delphi technique (in which consensus 
Table 2 Development, dissemination, and implementation strategies adopted by rigorous evaluations of guidelines for preventive care ${ }^{5}$

\begin{tabular}{|c|c|c|c|c|c|c|c|}
\hline Year & Authors & Subject & $\begin{array}{c}\text { Type of } \\
\text { guideline }\end{array}$ & Method of dissemination & Method of implementation & $\begin{array}{l}\text { Effect on } \\
\text { process }\end{array}$ & $\begin{array}{l}\text { Effect on } \\
\text { outcome }\end{array}$ \\
\hline 1978 & Morgan et $a l^{31}$ & Antenatal care & External national & $\begin{array}{l}\text { Guidelines discussed at } \\
\text { departmental meetings }\end{array}$ & $\begin{array}{l}\text { Failure to comply caused } \\
\text { computer generated } \\
\text { reminder after consultation }\end{array}$ & ++ & - \\
\hline 1982 & Cohen et $a l^{32}$ & Preventive care & External local & $\begin{array}{l}\text { Five seminars on preventive } \\
\text { medicine }\end{array}$ & $\begin{array}{l}\text { Copy of guidelines attached } \\
\text { to patients' notes }\end{array}$ & ++++ & - \\
\hline 1983 & Rodney et al ${ }^{33}$ & 2 Adult immunisations & External local & $\begin{array}{l}\text { Educational programme on } \\
\text { preventive medicine }\end{array}$ & $\begin{array}{l}\text { Medical record redesigned } \\
\text { to highlight health } \\
\text { maintenance (including } \\
\text { tetanus and pneumococcal } \\
\text { vaccinations) }\end{array}$ & ++ & - \\
\hline 1983 & $\begin{array}{l}\text { Thompson } \\
\text { et al }\end{array}$ & $\begin{array}{l}\text { Investigations in } \\
\text { "routine" physical } \\
\text { examinations }\end{array}$ & Intermediate & $\begin{array}{l}\text { Extensive educational } \\
\text { programme over } 2 \text { years }\end{array}$ & $2 \times$ aggregated feedback & +++ & - \\
\hline 1984 & $\begin{array}{l}\text { McDonald } \\
\text { et } a l^{35}\end{array}$ & $\begin{array}{l}9 \text { Preventive tasks and } \\
\text { six laboratory tests }\end{array}$ & External local & None reported & $\begin{array}{l}\text { Computer generated } \\
\text { reminder in notes }\end{array}$ & +++ & $\star$ \\
\hline 1984 & $\begin{array}{l}\text { Winickoff } \\
\text { et } \text { al }^{36}\end{array}$ & $\begin{array}{l}\text { Colorectal cancer } \\
\text { screening }\end{array}$ & Internal & $\begin{array}{l}\text { Regular meetings of } \\
\text { Department of Internal } \\
\text { Medicine }\end{array}$ & $\begin{array}{l}\text { Feedback of group and } \\
\text { individual compliance }\end{array}$ & ++ & - \\
\hline 1985 & Cohen $e t a l^{3 i}$ & 13 Preventive tasks & External local & Internal post & $\begin{array}{l}\text { Credit at university } \\
\text { bookshop after reading } \\
\text { guidelines }\end{array}$ & $\dagger$ & \\
\hline 1986 & $\begin{array}{l}\text { McDowell } \\
\text { et } \mathrm{al}^{38}\end{array}$ & Influenza vaccination & External national & None reported & $\begin{array}{l}\text { Computer generated } \\
\text { reminder in notes }\end{array}$ & ++ & - \\
\hline 1986 & Prislin $e a^{39}$ & 2 Preventive tasks & External local & $\begin{array}{l}\text { Conference on preventive } \\
\text { care and use of flowsheet }\end{array}$ & Flowsheet in patients' notes & ++++ & - \\
\hline 1986 & Tierney et $a l^{40}$ & 11 Preventive tasks & External local & Internal post & $\begin{array}{l}\text { (A) Computer generated } \\
\text { reminder in notes } \\
\text { (B) Computer generated } \\
\text { monthly feedback on patient } \\
\text { specific non-compliance }\end{array}$ & $\begin{array}{l}++ \\
+\end{array}$ & - \\
\hline 1987 & $\begin{array}{l}\text { Cheney and } \\
\text { Ramsdell }\end{array}$ & 12 Preventive tasks & External national & None reported & $\begin{array}{l}\text { Checklist placed in patients' } \\
\text { notes }\end{array}$ & ++ & - \\
\hline $\left.\begin{array}{l}1987 \\
1989\end{array}\right\}$ & Cohen $e t a l^{42+3}$ & Smoking cessation & External national & $\begin{array}{l}1 \text { hour lecture and booklet } \\
\text { on smoking cessation }\end{array}$ & $\begin{array}{l}\text { Two types of reminders in } \\
\text { patients' notes }\end{array}$ & ++++ & - \\
\hline $\begin{array}{l}1988 \\
1988\end{array}$ & Robie $^{44}$ & 3 Preventive tasks & External national & Lecture on cancer screening & Reminder in notes & +++ & - \\
\hline 1988 & $\begin{array}{l}\text { Schreiner } \\
\text { et } a l^{45}\end{array}$ & 4 Preventive tasks & External national & None reported & Reminder in notes & + & - \\
\hline 1988 & Wilson et al $^{\text {to }}$ & Smoking cessation & External national & $\begin{array}{l}4 \text { hour training in smoking } \\
\text { cessation }\end{array}$ & $\begin{array}{l}\text { Patients recruited by } \\
\text { receptionist }\end{array}$ & ++++ & + \\
\hline $\begin{array}{l}1989 \\
1989\end{array}$ & Becker et al ${ }^{47}$ & 9 Preventive tasks & External national & None reported & Reminder in notes & + & - \\
\hline 1989 & $\begin{array}{l}\text { Chambers } \\
\text { et } \mathrm{al}^{48}\end{array}$ & Mammography & External national & None reported & $\begin{array}{l}\text { Computer generated } \\
\text { reminder in notes }\end{array}$ & ++ & - \\
\hline 1989 & Cummings & Smoking cessation & National external & $\begin{array}{l}3 \text { hour continuing medical } \\
\text { educational programme }\end{array}$ & Reminder in notes & ++ & + \\
\hline 1989 & $\begin{array}{l}\text { McDowell } \\
\text { et } a l^{50}\end{array}$ & Blood pressure screening & External national & None reported & $\begin{array}{l}\text { Computer generated } \\
\text { reminder in notes }\end{array}$ & ++ & - \\
\hline 1989 & $\begin{array}{l}\text { McDowell } \\
\text { et } a l^{51}\end{array}$ & Cervical screening & External national & None reported & $\begin{array}{l}\text { Computer generated } \\
\text { reminder in notes }\end{array}$ & 0 & - \\
\hline 1989 & McPhee et al ${ }^{52}$ & 7 Preventive tasks & External national & None reported & $\begin{array}{l}\text { (A) Computer generated } \\
\text { reminder in notes } \\
\text { (B) Aggregated feedback }\end{array}$ & $\begin{array}{l}+++ \\
++\end{array}$ & - \\
\hline 1991 & McPhee et al $5^{33}$ & 11 Preventive tasks & External national & None reported & $\begin{array}{l}\text { Computer generated } \\
\text { reminder in notes }\end{array}$ & ++ & - \\
\hline 1991 & Rosser et $a l^{54}$ & Smoking cessation & External national & None reported & $\begin{array}{l}\text { Computer generated } \\
\text { reminder in notes }\end{array}$ & +++ & - \\
\hline 1992 & Cowan et $a l^{55}$ & 7 Preventive tasks & External national & None & $\begin{array}{l}\text { Guidelines placed in } \\
\text { patients' notes }\end{array}$ & + & - \\
\hline 1992 & Headrick et al ${ }^{56}$ & Cholesterol & External national & Lecture & $\begin{array}{l}\text { (A) Computer generated } \\
\text { reminder in notes } \\
\text { (B) Guidelines placed in } \\
\text { patients' notes }\end{array}$ & $\begin{array}{l}++ \\
+\end{array}$ & - \\
\hline 1992 & Lilford et $a l^{57}$ & Antenatal care & Intermediate & None reported & $\begin{array}{l}\text { New paper record or } \\
\text { computerised questionnaire }\end{array}$ & + & - \\
\hline 1992 & Rosser et al ${ }^{58}$ & Tetanus vaccination & National external & None reported & $\begin{array}{l}\text { Computer generated } \\
\text { reminder in notes }\end{array}$ & ++ & - \\
\hline
\end{tabular}

is achieved by successive circulation of a postal questionnaire); we have described these methods in detail elsewhere. ${ }^{71}$ Although all evaluated methods were successful in at least two studies, ${ }^{3}$ it is difficult to draw conclusions about which method is best in given circumstances. In many studies the method of development was not explicitly stated, in others the potential of a method of development is difficult to judge in the face of unsatisfactory dissemination and implementation strategies. For example, three studies evaluating guidelines developed by consensus conference found little change in medical practice (table 1). ${ }^{232429}$ However, the guide- lines were disseminated with little effort and without any attempt at implementation. In contrast, Lomas et al identified substantial improvements in performance when such guidelines on caesarean section were disseminated by a local "opinion leader", ${ }^{25}$ and Durand-Zaleski et al reported even greater improvements when guidelines on hypovolaemia were disseminated at local meetings and implemented through monthly feedback. ${ }^{26}$ From these five studies we can conclude that the successful introduction of guidelines developed by consensus conference is very dependent on the choice of appropriate dissemination and implementation strategies. 
Table 3 Development, dissemination, and implementation strategies adopted by rigorous evaluations of guidelines for prescribing and ancillary serices

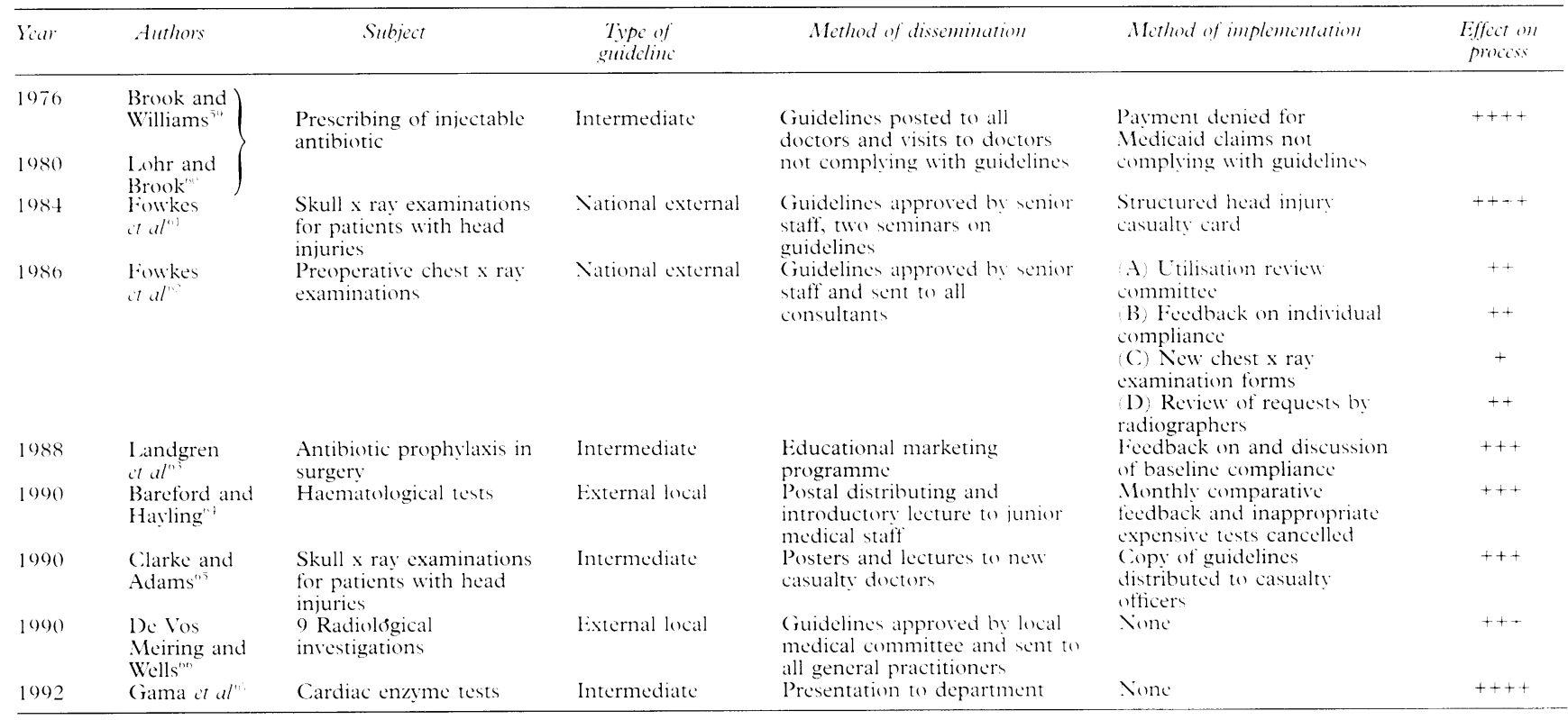

$+\quad$ Significant improvement $<10 \%$ in absolute terms.

+ Significant improvement $10-19.9 \%$ in absolute term

+++ Significant improvement $20.29 \cdot 9^{\circ} \%$ in absolute terms.

++++ Significant improvement $\$ 30 \%$ in absolute terms.

The studies also serve to illustrate why there is general uncertainty over whether clinical guidelines change medical practice.

HOW SHOLID GLIDLILINISS BE PRESLNII:1)?

There is little published information on the effect of the style and format of guidelines on their adoption. In the North of England study, peer groups of general practitioners showed considerable diversity in the style of their internal standards, ${ }^{(1)}$ but this did not prevent substantial improvements in process and outcome (table 1).$^{2 *}$ In contrast, the Harvard Community Health Plan has established a quality assurance programme based exclusively upon algorithms, ${ }^{74}$ building on their successful use as a method of information transfer in educational settings. ${ }^{i 5}$ However, doctors are often reluctant to use algorithms in everyday practice because of their apparent complexity and lack of flexibility. ${ }^{i \prime}$ A recent guideline for urinary incontinence sponsored by the Agency for Health Care Policy and Research $^{\text {is }}$ has responded to these criticisms by adopting an annotated algorithmic format incorporating literature citations and patient counselling notes.

Kahan et al analysed the content of 24 consensus statements by the National Institutes of Health (NIH) and suggested that variations in style may affect their acceptance by clinicians. ${ }^{79}$ Subsequently, the national institutes encouraged consensus development conferences to produce guidelines which were concrete (making specific recommendations), didactic (offering practical advice to the clinician), and differentiating (dividing patients into specific subclasses). Whatever format is chosen, it is important that the guideline is both reader friendly and comprehensive. $^{80}$ To meet these potentially conflicting demands many institutions now produce guidelines containing a short summary of the principal recommendations (which can be consulted in clinical practice), underpinned by detailed documentation about the process of guideline development and the scientific basis. Although more research is needed, it is reassuring to note that rigorously evaluated guidelines have achieved success with a wide range of styles and formats.

\section{Dissemination strategies}

Dissemination strategies aim at influencing targeted clinicians' awareness, attitudes, knowledge, and understanding of a set of guidelines. These strategies include publication in professional journals, postal distribution to relevant groups, incorporation within continuing medical education, and educational initiatives that focus specifically on the guidelines. Unfortunately, in many of the studies we reviewed, the method of dissemination was not explicitly stated.

Of the six studies that reported on guidelines disseminated without concurrent implementation strategies, three were consensus conferences that generated little or no change in clinical practice (table 1$) .23212$ Yet, one reported moderate success in reaching the appropriate target audience, and another found that $90 \%$ of doctors were "aware of the guidelines" and concluded that dissemination of "guidelines may predispose physicians to consider changing their behaviour but may not effect rapid change in the absence of other incentives." $=1$

Rodney et al were able to observe the effect of an educational programme on adult immunisation before the institution of implementation strategies; they observed little improvement in compliance before implementation (redesigning the medical records to highlight health maintenance activities 
including immunisation) but a significant improvement thereafter (table 2). ${ }^{33}$ Only two studies observed significant changes in clinical practice after the dissemination of guidelines without an explicit implementation strategy (table 3). ${ }^{66} 67$

In contrast, all the other successful studies we reviewed undertook implementation very soon after dissemination. Our review also suggests that the more overtly educational the dissemination strategy, the greater the likelihood that the guidelines will be adopted within clinical practice, provided that dissemination of guidelines is reinforced by an appropriate implementation strategy.

\section{Implementation strategies}

Implementation strategies are intended to encourage clinicians to change their own clinical practice in line with guidelines, and they may be divided into those that operate during or outside the doctor-patient consultation.

\section{STRATEGIES OPERATING DURING}

CONSULTATION

Implementation strategies operating within the doctor-patient consultation include general reminders of the guidelines, feedback specific to the previous care of individual patients, changes in medical records, and patient specific reminders at the time of consultation.

The simplest strategy is to provide clinicians with easily accessible copies of the guidelines; successful studies have used posters (tables $1,3)^{1265}$ or guidelines packaged in a format that can be easily carried. ${ }^{11}{ }^{63}$ Feedback specific to individual patients was successfully used in five studies (tables 1, 2). ${ }^{91416} 3140$ Successful changes to medical records have introduced computerised history taking 202757 or focused on a defined activity or condition (tables 1,3$).{ }^{33} 6162$

Several different methods have been used to provide patient specific reminders at the time of consultation. The simplest strategy is to place a copy of the guidelines in the patient's notes (tables 1, 2). ${ }^{10325556}$ For example, Cowan et al who did this with preventive care guidelines (without any further attempt at dissemination) observed significant improvements in the provision of preventive care (table 2). ${ }^{55}$ Other studies have placed a checklist, flowsheet, or reminder based on the guidelines in patient's notes. ${ }^{39} 41-454749$ In some studies guidelines were embedded in a supplementary medical record or investigation request form. For example, Wirtschafter et al provided Canadian community hospitals with medical record cards containing embedded protocols for specific neonatal emergencies, and they reported significant improvements in managing neonatal respiratory distress syndrome (table 1). ${ }^{22}$ Emslie et al reported improvements in general practice management and referral of infertile couples when guidelines were embedded within an infertility management package. ${ }^{30}$ Many studies have reminded doctors about previous non- compliance with guidelines at the time of consultation: patients' notes are screened before the consultation, either by a trained health care professional or more often by a computer, and reminders are placed only in those notes not complying with the guidelines (tables 1, 2). $.^{7811} 1315213538404850-545658$

\section{STRATEGIES OPERATING OUTSIDE}

\section{CONSULTATION}

Strategies operating outside the consultation that have been rigorously evaluated include aggregated feedback on compliance with guidelines, introducing financial incentives, explicit marketing, and peer review organisations. Feedback of aggregated data on performance is commonly used in medical audit but varies in its evaluated success. ${ }^{25} 263436526264$ Reporting on a direct financial incentive, Brook et al observed a dramatic reduction in the prescription of injectable antibiotics when payment was denied for claims not complying with the guidelines (table 3$)^{5960}$; reporting on an indirect financial incentive, Cohen et al observed that residents who were offered a credit at the university bookshop showed improved knowledge of the guidelines but only a "modest" increase in compliance (table 2). ${ }^{37}$ Several studies have used advertising campaigns to implement guidelines: for example, Landgren et al mounted a successful "educational marketing campaign" to implement guidelines for prophylactic antibiotic use in 12 Australian hospitals (table 3) ${ }^{63}$ Although the use of peer review organisations to stimulate change is mostly associated with the United States, the only two rigorous evaluations are British: Fowkes et al showed that a utilisation review committee successfully discouraged chest $x$ ray examinations $^{62}$ and Bareford and Hayling that professional monitoring reduced inappropriate laboratory testing. ${ }^{64}$

RELATIVE EFFECTIVENESS OF

IMPLEMENTATION STRATEGIES

Several studies have compared different implementation strategies. Fowkes et al compared four strategies to promote guidelines for routine preoperative chest $x$ ray examinations - namely, utilisation review committee, feedback on individual compliance, introduction of a new $x$ ray examination request form, and review of requests for $x$ ray examinations by radiologists: all were moderately successful, none more so than the other three (table 3). ${ }^{62}$ In a sequential study Sommers et al compared the effect on managing unexplained low haemoglobin concentration of two different types of feedback - aggregated versus patient specific feedback: they found that both strategies improved compliance but patient specific feedback was better (table 1). ${ }^{16}$ Lomas et al compared the effects of the traditional audit cycle with continuing education led by a local "opinion leader": they observed significant improvements in compliance with guidelines for caesarean sections only for the opinion 
leader. ${ }^{25}$ McPhee et al compared computer generated reminders placed in patients' notes with aggregated feedback to promote cancer screening; both strategies were successful but reminders were better (table 2). ${ }^{52}$ Headrick et al, comparing two strategies to improve compliance with National Cholesterol Education Program guidelines - namely, copies of the guidelines and computer generated reminders, both placed in patients' notes - showed that both strategies improved compliance but that reminders were better. ${ }^{50}$ Tierney et al compared the effects of two strategies on compliance with preventive care protocols - monthly patient specific feedback and patient specific reminders at the time of consultation - and they found that both strategies improved compliance but that reminders were better. ${ }^{40}$

In summary, implementation strategies operating within the consultation that focus on the management of individual patients are more likely to lead to changes in medical practice. Although there is little evidence on the relative effectiveness of strategies operating outside the consultation, they seem to have contributed substantially to the success of guidelines when they have been used.

\section{Discussion}

Clinical guidelines can change medical practice and achieve health gains. ${ }^{3}$ However, if guidelines are to achieve health gain through the contracting process purchasers and providers need to identify successful strategies for introducing them into clinical practice. Although literature reviews have begun to identify effective techniques for introducing clinical guidelines and to propose an agenda for future research, ${ }^{81.83}$ they have not attempted to quantify the relative effectiveness of different strategies.

In this paper we have shown that the introduction of clinical guidelines is a complex process with three crucial stages: creating a guideline (development), assimilation of the guideline by clinicians (dissemination), and ensuring clinicians act on the guideline (implementation). By examining the strategies adopted in rigorous evaluations of clinical guidelines we have previously identified those most likely to change medical practice. ${ }^{6}$ This review has reinforced our previous conclusions $^{\circ}$ - namely, that if guidelines are developed internally by the clinicians who are to use them few resources are needed to disseminate or implement them whereas successful introduction of guidelines developed externally needs much more

Table 4 Factors influencing the successful introduction of guidelines"

\begin{tabular}{llll}
\hline $\begin{array}{c}\text { Relative } \\
\text { probability of } \\
\text { being effective }\end{array}$ & $\begin{array}{c}\text { Development } \\
\text { strategy }\end{array}$ & Dissemination stratcgy & Implementation strategy \\
\hline High & Internal & $\begin{array}{l}\text { Specific educational } \\
\text { intervention } \\
\text { Continuing medical } \\
\text { education }\end{array}$ & $\begin{array}{l}\text { Patient specific reminder } \\
\text { at time of consultation } \\
\text { Patient specific feedback }\end{array}$ \\
$\begin{array}{l}\text { Below average } \\
\text { Low }\end{array}$ & Intermediate & $\begin{array}{l}\text { Eeneral feedback } \\
\text { Publication in professional } \\
\text { journal }\end{array}$ & $\begin{array}{l}\text { General reminder of } \\
\text { guidelines }\end{array}$ \\
\hline
\end{tabular}

emphasis on dissemination and implementation. Table 4 provides a basic framework for those using guidelines, but the evidence available on the relative effectiveness and efficiency of different strategies is still sparse.

Furthermore, only 10 of the studies reviewed were conducted in the United Kingdom; four of these were concerned with radiological investigations. It is therefore timely to explore this classification more thoroughly in the context of the restructured NHS. The challenge to those who evaluate guidelines in future is to provide rigorous evidence on the relative merits of different combinations of development, dissemination, and implementation strategies.

Despite this call for further research, three conclusions can be drawn. Firstly, clinical guidelines cannot achieve health gains unless they are scientifically valid (in the sense that they are rigorously developed and thus consistent with the available scientific evidence or, without such evidence, best clinical judgement. ${ }^{5}$ Secondly, clinical guidelines can achieve health gains if appropriate development, dissemination, and implementation strategies are adopted during their introduction. Thirdly, implementation strategies provide the key to the successful introduction of intermediate or external guidelines, which are potentially more valid'; in particular, implementation strategies that use information technology to focus on consultations with individual patients rather than general performance are very likely to change practice. This suggests that major advances will stem from the development of real time information systems in both hospital and general practice.

Finally, if guidelines are to achieve maximum benefit within the multidisciplinary NHS $^{\text {s. }}$ careful attention should be given in their introduction to the principles of change management ${ }^{\mathrm{s}}$; in particular, successful introduction needs leadership; energy; avoidance of unnecessary uncertainty; good communication; and, above all, time.

We thank Sheila Wallace for help with the literature review, the anonymous reviewer who provided helpful comments, and the Wellcome Trust and Chief Scientist Office of the Home and Health Department of the Scottish Office for funding JMG and Health Department of the Scottish Office for funding JMG and
ITR. The opinions expressed in this paper are those of the authors and not of the funding bodic.

1 Haines A, Feder $G$. Guidance on guidelines: writing them is easier than making them work. B.117 1992;305.

Anonymous. Guidelines for doctors in the new world. Lancet 1992;339:11978

3 Grimshaw JM, Russell IT. Effects of clinical guidelines on medical practice. A systematic review of rigorou cvaluations. Lancet 1993;342:1317-22

4 NHS Management Executive. Improcing clinical cffectivencs. Leeds: Department of Health, 1993. (EI (93) 115.$)$

5 Grimshaw JM, Russell I'T. Achieving health gain through clinical guidelines: I. Developing scientifically valid guidelines. Ouality in Health Care 1993;2:243-8.

6 Russell IT, Grimshaw JM. The effectiveness of referral guidelines: a review of the methods and findings of Hospital referrals. Oxford: Oxford University Press, 1002 . 179-211.

McDonald (J. Use of a computer to detect and respond to clinical events: its effect on clinician behaviour. Am Intern Mid $1076 ; 84: 102-$ 
$8 \mathrm{McDonald}$ CJ. Protocol-based computer reminders, the quality of care and the non-perfectability of man. N Engl f Med 1976;295:1351-5.

9 Barnett GO, Winickoff R, Dorsey JL, Morgan M, Lurie RS. Quality assurance through automated monitoring and concurrent feedback using a computer-based medical information system. Med Care 1978;16:962-70.

10 Sanazaro PJ, Worth RM. Concurrent quality assurance in hospital care. $N$ Engl f Med 1978;298:1171-7.

11 Hopkins JA, Shoemaker WC, Greenfield S, Chang PC, McAuliffe T, Sproat RW. Treatment of surgica emergencies with

12 Linn BS. Continuing medical education: impact on emergency room burn care. $\mathcal{F A M A}$ 1980;244:565-70.

13 McDonald CJ, Wilson GA, McCabe GP. Physician response to computer reminders. $\mathcal{J} A M A$ $1980 \cdot 244:$

14 Barnett GO, Winickoff RN, Morgan MM, Zielstorff RD. A computer-based monitoring system for follow-up of elevated blood pressure. Med Care 1983;21:400-9.

15 Thomas JC, Moore A, Qualls PE. The effect on cost of medical care for patients treated with an automated clinical audit system. F Med Syst 1983;7:307-13.

16 Sommers LS, Scholtz R, Shepherd RM, Starkweather DB. Physician involvement in quality assurance. Med Care 1984;22:1115-38.

17 Norton PG, Dempsey LJ. Self-audit: its effect on quality of care. 7 Fam Pract 1985;21:289-91.

18 Palmer RH, Louis TA, Hsu L-N, et al. A randomised controlled trial of quality assurance in sixteen ambulatory care practices. Med Care 1985;23:751-70

19 Putnam RW, Curry L. Impact of patient care appraisal on physician behavior in the office setting. Can Med Assoc 7 1985;132:1025-9.

20 Brownbridge G, Evans A, Fitter M, Platts $M$. An interactive computerised protocol for the management of hypertension: effects on general practitioner's clinical behaviour. F $R$ Coll Gen Pract 1986;36:198-202.

21 McAlister NH, Covvey HD, Tong C, Lee A, Wigle ED. Randomised controlled trial of computer assisted management of hypertension in primary care. $B M \mathcal{F}$ 1986;293:670-4.

22 Wirtschafter DD, Sumners J, Jackson JR, Brooks CM, Turner M. Continuing medical education using clinical algorithms: a controlled-trial assessment of effect on neonatal care. Am $\mathcal{F}$ Dis Child 1986;140:791-7.

23 Kosecoff J, Kanouse DE, Rogers WH, McCloskey L, Winslow CM, Brook RH. Effects of the National Institutes of Health consensus development program on physician practice. $\mathcal{F} A M A 1987 ; 258: 2708-13$.

24 Lomas J, Anderson GN, Domnick-Pierre K, Vayda E, Enkin MW, Hannah WJ. Do practice guidelines guide practice? The effect of a consensus statement on the practice? The effect of a consensus statement on the
practice of physicians. $N$ Engl $f$ Med 1989;321: practice $1306-11$.

25 Lomas J, Enkin M, Anderson GN, Hannah WJ, Vayda E, Singer J. Opinion leaders vs audit and feedback to implement practice guidelines: delivery after previous caesarean section. $\mathcal{F} A M A$ 1991;265:2202-7.

26 Durand-Zaleski I, Bonnet F, Rochant H, Bierling P, Lemaire F. Usefulness of consensus conferences: the case of albumin. Lancet 1992;340:1388-90.

27 Margolis CZ, Warshawsky SS, Goldman L, Dagan O, Wirtschafter D, Pliskin JS. Computerised algorithms and pediatricians' management of common problems in a community clinic. Acad Med 1992;67:282-4.

28 North of England Study of Standards and Performance in General Practice. Medical audit in general practice: effects on doctors' clinical behaviour and the health of patients with common childhood conditions. BMF 1992;304:1480-8.

29 Sherman CR, Potosky AL, Weis KA, Ferguson JH. The consensus development program: detecting changes in medical practice following a consensus conference on the treatment of prostate cancer. Int $\mathcal{F}$ Tech Assess in Health Care 1992;8:683-93.

30 Emslie CJ, Grimshaw J, Templeton A. Do clinical guidelines improve general practice management and referral of infertile couples? BMf 1993;306:1728-31.

31 Morgan M, Studney DR, Barnett GO, Winickoff RN. Computerised concurrent review of prenatal care. Qual Rev Bull 1978;4:33-6.

32 Cohen DI, Littenberg B, Wetzel C, Neuhauser DB. Improving physician compliance with preventive medicine guidelines. Med Care 1982;20:1040-5.

33 Rodney WM, Chopivsky P, Quan M. Adult immunisation: the medical record design as a factor for physician compliance. f Med Educ 1983;58:576-80.

34 Thompson RS, Kirz HL, Gold RA. Changes in physician behavior and cost savings associated with organisational recommendations on the use of routine chest x-rays and multichannel blood tests. Prev Med 1983;12:385-96.

35 McDonald CJ, Hui SL, Smith DM, et al. Reminders to physicians from an introspective computer medical record: a two year randomised trial. Ann Intern Med 1984;100: $130-8$

36 Winickoff $\mathrm{RN}$, Coltin $\mathrm{KL}$, Morgan $\mathrm{M}$, Buxbaum RC, Barnett GO. Improving physician performance through peer comparison feedback. Med Care 1984;22:527-34.

37 Cohen SJ, Weinberger M, Hui SL, Tierney WM, McDonald CJ. The impact of reading on physicians' non-adherence to recommended standards of medical care. Soc Sci Med 1985;21:909-14.

38 McDowell I, Newell C, Rosser W. Comparison of three methods of recalling patients for influenza vaccination. Can Med Assoc 7 1986;135:991-7.

39 Prislin MD, Vandenbark MS, Clarkson QC. The impact of health screening flow sheet on the performance and documentation of health screening procedures. Fam Med 1986;18:290-2.

40 Tierney WM, Hui SL, McDonald CJ. Delayed feedback of physician performance versus immediate reminders to perform preventive care. Med Care 1986;24:659-66.

41 Cheney C, Ramsdell JW. Effect of medical records' checklists on implementation of period health measures. Am f Med 1987;83:129-36.

42 Cohen SJ, Christen AG, Katz BP, et al. Counselling medical and dental patients about cigarette smoking: the impact of nicotine gum and chart reminders. Am $\mathcal{F}$ Public Health 1987;77:313-6.

43 Cohen SJ, Stookey GK, Katz BP, Drook CA, Smith DM. Encouraging primary care physicians to help smokers quit: a randomised controlled trial. Ann Intern Med 1989;110:648-52.

44 Robie PW. Improving and sustaining outpatient cancer screening by medicine residents. South Med $f$ 1988;81:902-5.

45 Schreiner DT, Petrusa ER, Rettie CS, Kluge RM. Improving compliance with preventive medicine procedures in a house staff training program. South Med procedures in a hous

46 Wilson DM, Taylor DW, Gilbert JR, et al. A randomised trial of a family physician intervention for smoking cessation. $\mathcal{F} A M A$ 1988;260:1570-4.

47 Becker DM, Gomez EB, Kaiser DL, Yoshihasi A, Hodge $\mathrm{RH}$. Improving preventive care at a medical clinic: how can the patient help? Am F Prev Med 1989;5:353-9.

48 Chambers CV, Balaban DJ, Carlson BL, Ungemack JA, Grasberger DM. Microcomputer-generated reminders: improving the compliance of primary care physicians with mammography screening guidelines. I Fam Pract 1989;29:273-80.

49 Cummings SR, Coates TJ, Richard RJ, et al. Training physicians in counselling about smoking cessation: a randomised trial of the "Quit for life" program. Ann Intern Med 1989;110:640-7.

50 McDowell I, Newell C, Rosser W. A randomized trial of computerised reminders for blood pressure screening in primary care. Med Care 1989;27:297-305.

51 McDowell I, Newell C, Rosser W. Computerized reminders to encourage cervical screening in family practice. $f$ Fam Pract 1989;28:420-4.

52 McPhee SJ, Bird JA, Jenkins CN, Fordham D. Promoting cancer screening: a randomized controlled trial of three interventions. Arch Intern Med 1989;149:1866-72.

53 McPhee SJ, Bird JA, Fordham D, Rodnick JE, Osborn EH. Promoting cancer prevention activities by primary care physicians: results of a randomized controlled trial. ҰAMA 1991;266:538-44.

54 Rosser WW, McDowell I, Newell C. Use of reminders for preventive procedures in family medicine. Can Med Assoc f 1991;145:807-14

55 Cowan JA, Heckerling PS, Parker JB. Effect of a fact sheet reminder on performance of the periodic health examination: a randomized controlled trial. Am $\mathcal{F}$ Prev Med 1992;8:104-9.

56 Headrick LA, Speroff T, Pelecanos HI, Cebul RD. Efforts to improve compliance with national cholesterol program guidelines: results of a randomized controlled trial. Arch Intern Med 1992;152:2490-6.

57 Lilford RJ, Kelly M, Baines A, et al. Effect of using protocols on medical care: randomised trial of three
methods of taking an antenatal history. BMF methods of taking

58 Rosser WW, Hutchison BG, McDowell I, Newell C. Use of reminders to increase compliance with tetanus booster vaccination. Can Med Assoc $\mathcal{F}$ 1992;146:911-7.

59 Brook RH, Williams KN. Effect of medical care review on the use of injections: a study of the New Mexico Experimental Care Review Organisation. Ann Intern Med 1976;85:509-15.

60 Lohr KN, Brook RH. Quality of care in episodes of respiratory illness among Medicaid patients in New Mexico. Ann Intern Med 1980;92:99-106.

61 Fowkes FGR, Williams LA, Cooke BRB, Evans RC, Gehlbach SH, Roberts CJ. Implementation of guidelines for the use of skull radiographs in patients with head for the use of skull radiographs
injuries. Lancet 1984;ii:795-7.

62 Fowkes FGR, Davies ER, Evans KT, et al. Multicentre trial of four strategies to reduce use of a radiological test. Lancet 1986;i:367-70

63 Landgren FT, Harvey KJ, Mashford ML, Moulds RFW, Guthrie B, Hemming M. Changing antibiotic prescribing by educational marketing. Med f Aust 1988;149: 595-9.

64 Bareford D, Hayling A. Inappropriate use of laboratory services: long term combined approach to modify request patterns. BMf 1990;301:1305-7.

65 Clarke JA, Adams JE. The application of clinical guidelines for skull radiography in the accident and emergency department: theory and practice. Clin Radiology 1990; 41:152-5.

66 De Vos Meiring P, Wells IP. The effect of radiology guidelines for general practitioners. Fournal of Clinical Radiology 1990; 42:327-9.

67 Gama R, Nightingale PG, Ratcliffe JG. Effect of educational feedback on clinicians' requesting of cardiac enzymes. Ann Clin Biochem 1992;29:224-5.

68 Brook RH. Practice guidelines and practising medicine: are 
they compatible? $7 A M A$ 1989;262:3027-30.

69 Grol R. Quality assurance: approaches to standard setting, assessment and change. Atencion Primari 1990;7: $737-41$

70 North of England Study of Standards and Performance in General Practice. An oreviez of the studs. Newcastle upon Tyne: Centre for Health Services Research, 1991. (Report 50.)

71 Newton JC, Hutchinson A, Steen IN, Russell IT, Haines EV. Educational potential of medical audit: observations from a study of small groups setting standards. Quality in from a study of small groups

72 Russell IT, Grimshaw JM, Wilson BJ. Scientific and methodological issues in quality assurance. In: Beck IS, Bouchier IAD, Russell II, medical care. Procedings of the Rolal Socicty of Edinburgh 1993;101B: $77-103$

73 Clinical Resource and Audit Group. Clinical guidelines. Edinburgh: Scottish Office Home and Health Department, 1993.

74 Schoenbaum SC, Gottlieb LK. Algorithm based improvement of clinical quality. BMF 1990;301:1374-6.

75 Margolis CZ, Cook CD, Barak N, Adler A, Geertsma A. Clinial algorithms teach pediatric decisionmaking more Clinial algorithms teach pediatric decisionmaking

76 North of England Study of Standards and Performance in General Practice. Final Report: I - setting clinical standards in small groups. Newcastle upon Tyne: Health Care Research Unit, 1990. (Report 40.)
77 Institute of Medicine. Guidelines for clinical practice: from developincut to use. Washington, IC: National Academ Press, 1992: 248-9.

78 Hadorn DC, McCormick K, Diokno A. An annotated algorithm approach to clinical guideline development. 7AMA 1992;267:3311 +

79) Kahan JP, Kanouse DE, Winkler JI). Stylistic variations in National Institutes of Health consensus statements,

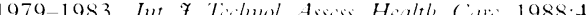
$289-30.4$

80 Kanouse DE: Jacoby I. When does information change practitioners behaviour? Int 7 Tichnol Awiow Hialth cian 1988:4:27.33.

81 I omas J, Harnes RB. A taxonomy and critical rericw of tested strategies for the application of clinical practice recommendations: from "official" to "individual" clinical policy. Am F Prer Mid 1987;4:77-94.

82 (irol R. Implementing guidelines in general practice care Quality in Health Cari 1992;1:18491.

83 Mittman BS, Tonesk X, Jacobson PI). Implementing clinical practice guidelines: social influence strategies and practitioner behaviour change. Qual Re\% Bull 1992;18:413-22.

84 McNicol M, Lavton A, Morgan (3. Team working: the key to implementing guidelines. Quality in Hicalth (ial 1993;2: 215-6.

85 Beckhard R, Harris J. (Organisational transitions: managins. complex change. Ind ed. Iondon: Addison-Wesley, 1989 